"Submarine Mass Movements and Their Consequences 4th International Symposium » Austin, Texas, November 8 $-11,2009$

2009 ; Special volume

In Press

(c) 2009 Bureau of Economic Geology, Jackson School of

Geosciences in Austin
Archimer

Archive Institutionnelle de

I'Ifremer

http://www.ifremer.fr/docelec/

http://www.beg.utexas.edu/indassoc/dm2/Conference2009/home.htm

\title{
Mass-transport deposits on the Algerian margin (Algiers area): morphology, lithology and sedimentary processes
}

\author{
Gabriela Dan ${ }^{1,2,5,{ }^{*}}$, Nabil Sultan ${ }^{1}$, Antonio Cattaneo ${ }^{1}$, Jacques Déverchère ${ }^{2,3}$ and \\ Karim Yelles ${ }^{4}$
}

${ }^{1}$ IFREMER, Géosciences Marines, Laboratoire Environnements Sédimentaires, Plouzané, France

${ }^{2}$ Université de Brest ; CNRS, UMR 6538 Domaines Océaniques; Institut Universitaire Européen de la Mer, Place Copernic, 29280 Plouzané, France

${ }^{3}$ Université Européenne de Bretagne, Brest, France

${ }^{4}$ CRAAG, Centre de Recherche en Astronomie, Astrophysique et Géophysique, Bouzaréah, Algiers, Algeria

${ }^{5}$ Present affiliation: FUGRO FRANCE S.A.S, 27 Rue des Peupliers, 92752, Nanterre, France

*: Corresponding author : G. Dan, email address : G.Dan@fugro.com

\begin{abstract}
:
On 21st May 2003, a damaging earthquake of Mw: 6.9 struck the region of Boumerdès $40 \mathrm{~km}$ east of Algiers in northern Algeria. The seismic shocks had devastating effects in the offshore area between the cities of Algiers and Dellys, where numerous cable breaks were observed. The submarine area encompassing the 2003 Boumerdès epicenter (central Algerian margin) was recently investigated using geophysical and sampling tools. It has been observed that small-size slides and mass-transport deposits occur across this area. Thus, a detailed analysis was performed on 25 submarine slides identified in water depth from $500 \mathrm{~m}$ to $2700 \mathrm{~m}$, by measuring different morphological parameters (i.e. surface, head-scarp height, slope in the source area and in adjacent areas). Various deposits consisting of matrix supported mud-clast, distorted stratified sediments and sandturbidite beds were observed in gravity cores near and within the most significant-size slide. Based on this work and previous studies it can be presumed that the recurrent seismic activity can be considered as the main triggering factor for failure in the central Algerian margin.
\end{abstract}

Keywords: Algeria, mass-transport deposit, morphology, triggering mechanism.

\section{Introduction}

The Algerian margin is a former passive margin reactivated by compression and characterized by moderate to high seismicity (Palaez Montilla et al. 2003). The last significant earthquake occurred in 2003 offshore the city of Boumerdès and the main shock was widely felt within a radius of approximately $400 \mathrm{~km}$ in Algeria. An associated tsunami was felt in southeastern Spain, including the Balearic Islands, 
Sardinia and also southern France (Alasset et al., 2006). In addition, a shoreline uplift marked by a continuous white band visible at rocky headlands (emerged algae) occurred between the cities of Boumerdes and Dellys (Meghraoui et al. 2004). Based on the numerous cable breaks observed on 5 different communication cables (France Telecom 2003), it has been presumed that large volume of sediment have probably been destabilized during the earthquake and after-shocks.

Following the Boumerdès event, numerous studies focussed on the area offshore of the epicenter in order to identify related tectonic deformation and earthquake-triggered deposits (Déverchère et al. 2005; Domzig et al. 2006; Dan 2007; Dan et al. 2008; Domzig et al. 2008; Yelles et al. 2009; Cattaneo et al. this volume). The central Algerian margin is characterized by a continental shelf of variable width and a steep continental slope (Fig. 1). The abyssal plain exhibits a complex morphology, with several curvilinear escarpments (S1 and S2, Fig. 1) probably representing the expression of active tectonic deformation in the area (Déverchère et al. 2005) and a large-scale deep-sea fan (Algiers Deep-Sea Fan, ADSF, Fig. 1). Well-developed canyons and slide scars shape the continental slope and the curvilinear escarpments (Dan 2007; Domzig et al. 2008). Salt diapirs of different shape, length and orientation are also present within the abyssal plain (Fig. 1; Gaullier et al. 2004; Domzig et al. 2006).

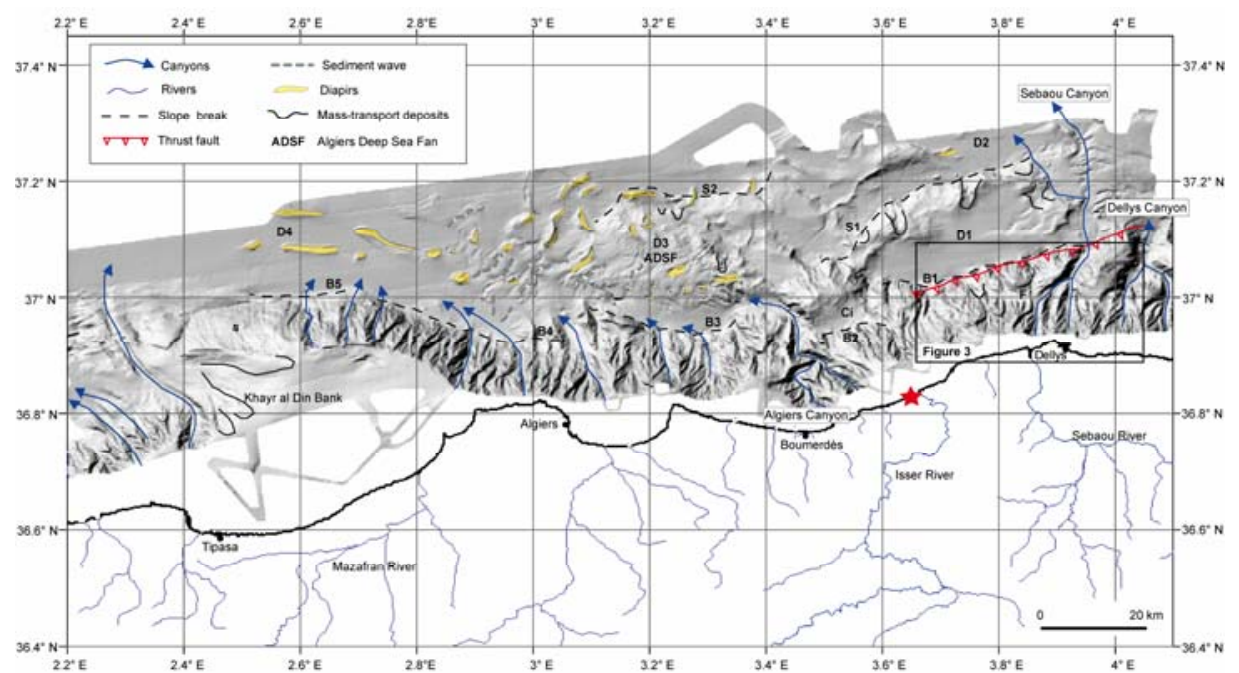

Figure 1: Shaded relief map showing the main morphological features in the study area. Slope breaks delimiting the continental slope: B1 to B5; slope breaks delimiting the deep curvilinear escarpments: S1 and S2; Deep basins: D1 to D4 (modified from Dan et al. 2008); Thrust fault location is from Déverchère et al. (2005). Red star is the 2003 Boumerdès epicenter (Semmane et al. 2005).

Numerous small-scale slides and MTDs were identified and mapped across the Algerian margin based on the seafloor analysis and seismic echo-facies (Dan 2007; Domzig et al. 2008; Cattaneo et al. this volume). Recent studies focused on a few selected cases (S1 escarpment-Dan et al. 2008; S2 escarpment-Nouguès et al. this volume) allowed the identification of triggering mechanism of different slope failures. Slope stability evaluation under gravity loading, where only the static physical properties of the sediments (unit weight, internal friction angle and undrained shear strength) are considered, showed that failure does not occur for a slope value of $5^{\circ}$ (Dan et al. 2008). In contrast, numerical calculations carried out on the S1 escarpment under cyclic loadings showed that slope failure may occur during an earthquake characterized by a PGA in excess of $0.1 \mathrm{~g}$, and also that liquefaction could be triggered in shallow silty-sandy deposits under a PGA of $0.2 \mathrm{~g}$ (Dan et al. 2008). This PGA value is typically the one assumed in northern Algeria using spatially smoothed seismicity data (Pelaez Montilla et al. 2003). 
In the present paper our attention focuses on the morphological description of the eastern part of the continental slope offshore the city of Dellys, where the seafloor imprint of the Boumerdès fault has been mapped (Déverchère et al. 2005; Domzig et al. 2006) (Figs. 1 and 2). In addition, the study deals with the moprhometric analysis of 25 slides identified across the central Algerian margin in order to assess the influence of the slope angle or other morphological parameter in terms of the triggering mechanism. Furthermore, a detailed morphological presentation of the largest slide, the B1 Slide, is per-

formed based on the bathymetry, high-resolution side-scan sonar data and gravity cores.

\section{Data and Methods}

The geophysical data consist of swath bathymetry (Kongsberg Simrad EM-300 and EM 1000 echosounder) from the MARADJA survey (Déverchère 2003). Deep-towed sidescan sonar images were collected during the MARADJA2 survey (Savoye 2005). Three Küllenberg cores acquired during the MARADJA2 cruise across the B1 Slide illustrate the sedimentary facies with lithologic logs, photographs and X-ray images. Sediment samples taken from two cores help constrain the age of the sediment with the performance of AMS radiocarbon dating on foraminifera tests (Globigerinoides and Orbulina). A detailed morphological analysis has been carried out on twenty-five slides within the Algiers area. The identification of slides was mainly based on the bathymetry analysis where the slide scars have distinct signature and convex-up slide deposits are sometimes associated. Two types of slides were distinguished based on the run-out distance: highmobility slides with large run-out distances able to produce an evacuation zone, and low-mobility slides with short run-out that permit to have a defined downdip depositional lobe. The different morphological parameters measured on the twenty-five slides are: 1) water depth at the headwall scarp, 2) total length from the headwall to the tip of the deposit (run-out), 3) slide scar width, 4) gradient in the slide scar area, 5) gradient in the adjacent unfailed area, 6) height of the headwall scarp, 7) slide surface area, and 8) slide volume. The volume was calculated as: $\mathrm{V}=1 / 2(\mathrm{~A})(\mathrm{h} \cos \alpha)$; where $\mathrm{A}$ is the area of the scar, $\mathrm{h}$ is the headscarp height and $\alpha$ is the scar slope angle (McAdoo et al. 2000).

\section{Results}

\subsection{Morphology}

For the morphometric study we measured parameters on 25 selected submarine slides. The selection of these 25 slides was done with the mentality to sample many different environments: on the continental slope offshore Dellys (B1 Slide), along the S1 escarpment (6), along the S2 escarpment (8), on the Khayr al Din bank (7), and east of the Algiers submarine canyon (3). Based on the seafloor imprint, most of the slides are considered as high-mobility failures since associated deposits were rarely recognized near the slide scar. The studied slides occur in water depths ranging from 700 to 2800 meters (Fig. 2a), and are characterized by an average total length of $1.6 \mathrm{~km}$ and approximately $0.6 \mathrm{~km}$ in width (Figs 2b and 2c). 
The head-scarp height varies from 5 to 60 meters (Fig. 2d). Generally, the slope angle where slides occur is ranging from 1 to $14^{\circ}$, and the resulting slope angle within the slide scars ranges from 4 to $24^{\circ}$ (Figs. 2e and 2f). All slides, excluding the B1 Slide, have an average surface area of $0.2 \mathrm{~km}^{2}$ (Fig. $2 \mathrm{~g}$ ), while the average volume is approximately $0.003 \mathrm{~km}^{3}$ (Fig. 2h).

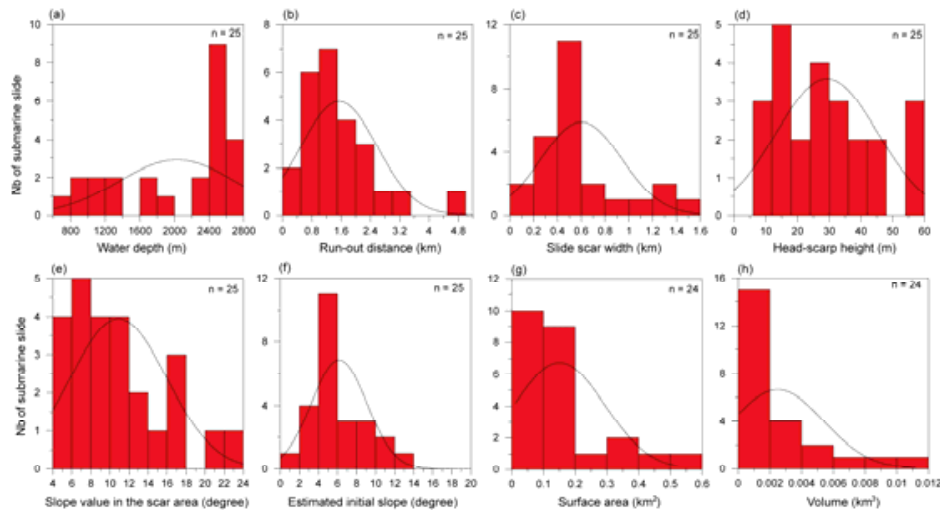

Figure 2: Histograms showing the main morphometric parameters of the 25 slides: (a) water depth; (b) run-out distance; (c) slide scar width; (d) headscarp height; (e) slope within the scar area; (f) initial slope; (g) surface area and (h) volume.
The continental shelf offshore Dellys presents a variable width (1 to $4 \mathrm{~km}$ ), while the continental slope ranges from 10 to $20 \mathrm{~km}$ in width and is characterized by the presence of a W-E directed intermediary slope break. Two major canyons in-

cise the eastern slope while gully-like features affect the rest of the slope (Fig. 3). Submarine slides, observed as slide scars, appear located across the continental slope and within the canyons system (head, flanks and intra-canyons area). Obviously, Fig. 3 illustrates the variety of slides that occur across this part of the Algerian margin.

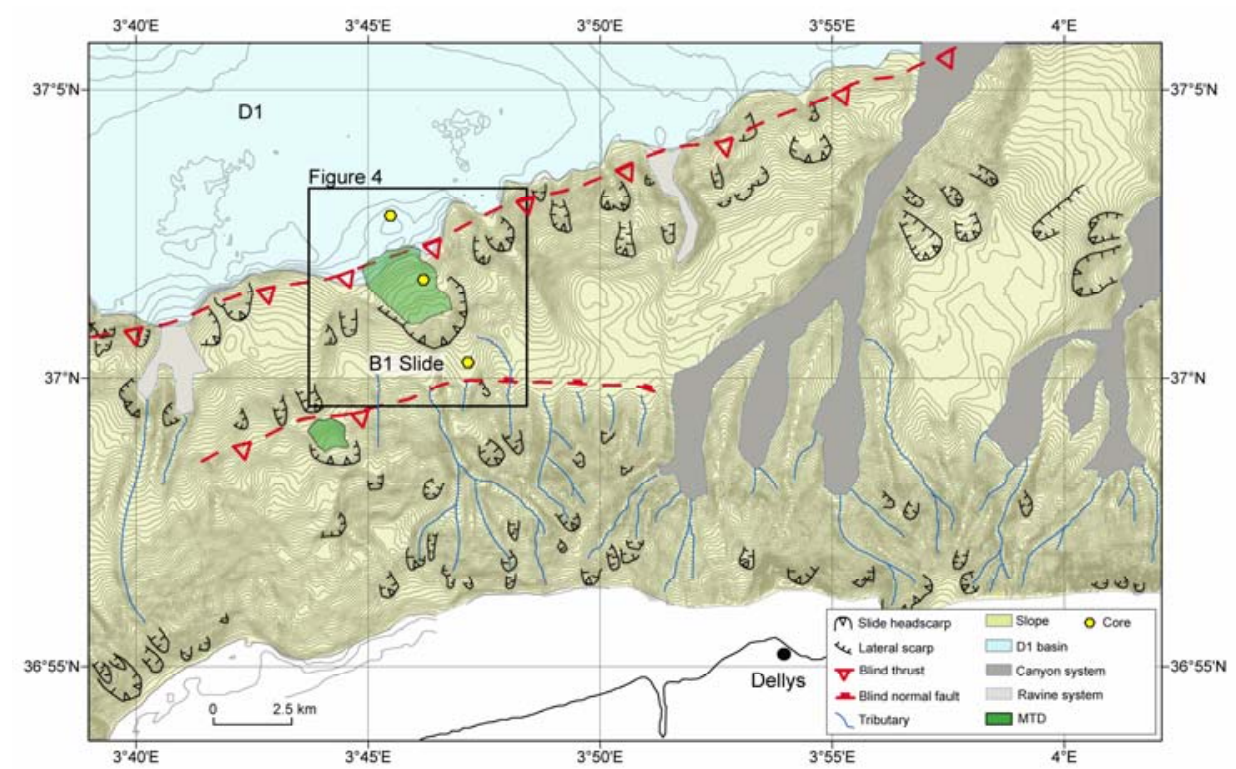

Figure 3: Bathymetric map showing the main morphological features within the area offshore the town of Dellys. The blind thrust path is from Déverchère et al. (2005).

Among these failures, the B1 Slide that exhibits a significant size was the object of a more detailed study (Fig. 4). The B1 Slide scar is located approximately $11 \mathrm{~km}$ seaward of the coastline offshore the city of Dellys, and occurs in a water depth of 1750 meters. 
The B1 Slide headwall is approximately $200 \mathrm{~m}$ in height and approximately $1.5 \mathrm{~km}$ in width (Fig. 4b). The slide scar has an amphitheatre-shape and part of the failed sediment is deposited on the continental slope between the steep lateral walls of the failure; thus the B1 Slide is considered as low-mobility (Figs. 4b, 4c). The slide covers a significant surface area of $4.7 \mathrm{~km}^{2}$ and the estimated volume of failed sediment is approximately $0.20 \mathrm{~km}^{3}$.
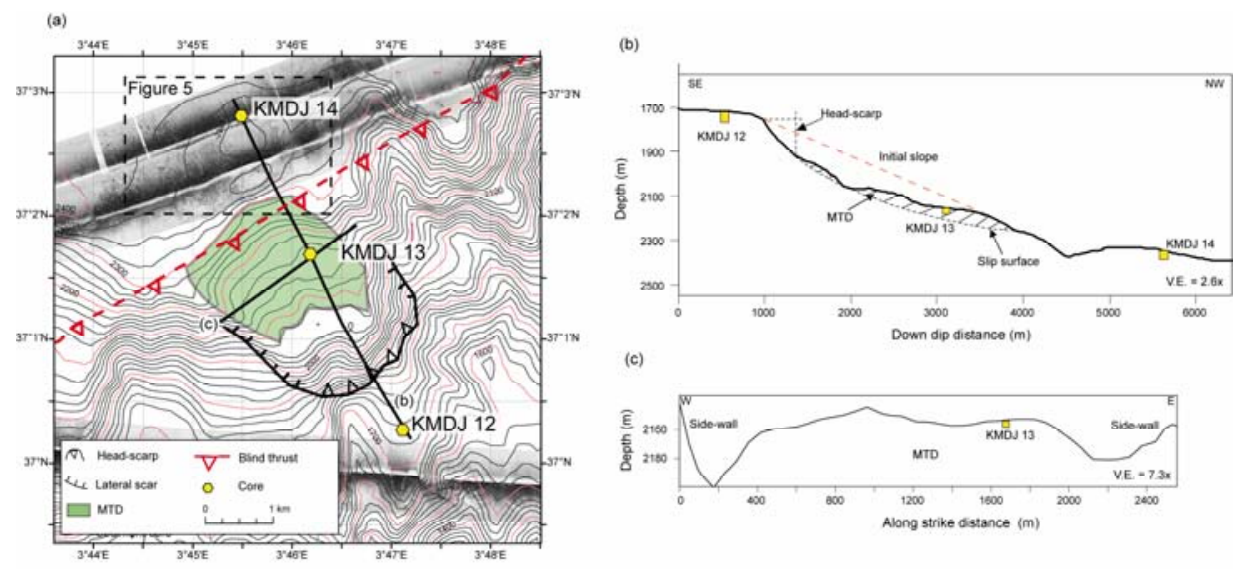

Figure 4: a) Bathymetric map showing the B1 Slide location; b) Down dip bathymetric profile and c) Along strike bathymetric profile across the B1 Slide. The slide scar (black line) and the slide deposit (green) are clearly distinguishable. The blind thrust path is from Déverchère et al. (2005).

The side-scan sonar image located at the foot of the slope, downslope of the B1 Slide where the core KMDJ-14 was sampled is presented in Fig. 5. Areas of high backscatter (dark tones) are probably erosional tracks or linked to the presence of coarse-grained sediment (dark grey shadows). The backscatter image shows various sonar contacts identified as sub-circular features with a relief above the surrounding seafloor that are interpreted as blocks. These blocks are characterized by variable size with length between 2.5 and 50 meters. Out-runner blocks are visible with backscatter images to a maximum distance of $7 \mathrm{~km}$ from the headwall, but they could probably reach distance beyond the coverage of the side-scan sonar survey.

Another interesting feature on the backscatter image is the presence of rectilinear glide tracks showing a slight radial direction by comparison with the longitudinal axis of the

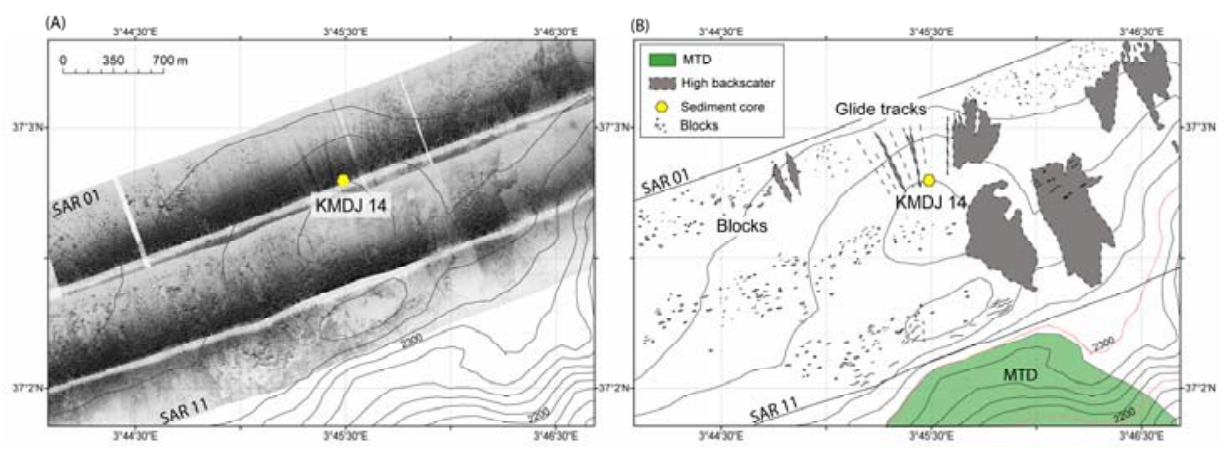

Figure 5: a) Side-scan sonar image recovered at the foot of the slope and b) Interpretation of the SAR image.

B1 Slide (Fig. 5). These glide tracks are particularly evident at the location of core KMDJ 14 and show high backscatter values (Fig. 5). The spacing of such glide tracks is in the order of $50 \mathrm{~m}$ and their maximum width is approximately $25 \mathrm{~m}$. 


\subsection{Lithology and age of sediment}

Three gravity cores were recovered along the B1 Slide on a longitudinal transect in order to recover sediment upslope the headwall scarp (KMDJ-12), the deposit within the slide scar (KMDJ-13), and the slide deposit in a more distal location (KMDJ-14).

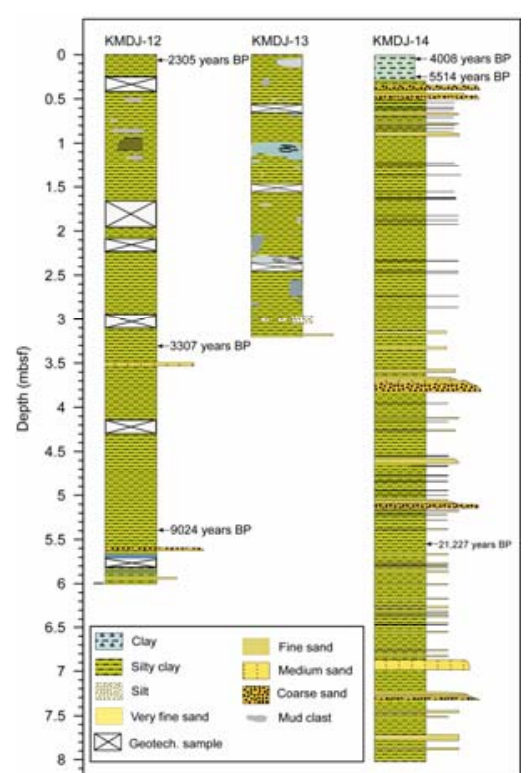

Figure 6: Interpreted logs of core KMDJ-12, KMDJ-13 and KMDJ-14. Location of cores is in Fig. 4.
Core KMDJ-12 is $6 \mathrm{~m}$ long and was recovered upslope the headwall of the B1 Slide in a water depth of $1700 \mathrm{~m}$ (Fig. 6). The sediment consists of a few centimeters of brown soft clay deposit overlying an approximately $2 \mathrm{~m}$ thick bed of soft mud clasts supported by a brown clay matrix (Fig. 6). The mud clasts are of various color (grey, beige) and size (1 to $5 \mathrm{~cm}$ ) (Fig. 7a). Thin colored (grey, blue) clay laminae appear folded within the clayey matrix (Figs. 7b and 7c). Three cm-scale medium sand turbidite beds were recognized at 3.5, 5.6 and 5.9 meters below seafloor (mbsf). A blue hard mud clast lies between the deepest two sandy beds.

Core KMDJ-13 is $3 \mathrm{~m}$ long and was recovered in a water depth of $2132 \mathrm{~m}$ within the B1 Slide (Fig. 6). The sediment from the entire core consists of hard and soft clay clasts, characterized by various sizes and colors (Fig. 7d). A large (around $15 \mathrm{~cm}$ in diameter) overconsolidated clay block is observed from 1 to 1.16 mbsf. This block presents sharp limits and an internal structure characterized by very thin silt and clay deformed laminae (Fig. 7g). It can be presumed that sediment from core KMDJ-13 is part of the failed sediment deposited $3 \mathrm{~km}$ downslope the headwall scarp.

Core KMDJ-14 is $8 \mathrm{~m}$ long and is located at the foot of the slope in a water depth of $2312 \mathrm{~m}$ (Fig. 6). The sediment at the top of the core consists of $35 \mathrm{~cm}$ of soft brown homogenous clay that overlies two coarse-grained sand beds. The sand beds are 3 to $5 \mathrm{~cm}$ thick and two cm-size pebbles exist between these two beds. From these coarsesand layers to the bottom of the core, the sediment consists of alternating fine to coarsegrained sand turbidite beds with soft clay intervals. Approximately twenty-five turbidite beds were counted along the core characterized by an average thickness of $8 \mathrm{~cm}$ (Fig. 6). The thickest turbidites exhibit a fining-up grading and erosive medium to coarse-grained sand bases.

Five AMS ${ }^{14} \mathrm{C}$ dates are done in cores KMDJ-12 and KMDJ-14 (Fig. 6). The uppermost date performed above the MTD (KMDJ-12) provided an evaluation of its age. The age of approximately 2300 years BP suggests one of these scenarios: a) the MTD is ancient, so it is not linked, for example, with the 2003 Boumerdès event; b) the dating sample was contaminated by older foraminifera tests due to sediment disturbance; c) the uppermost part of sedimentary succession at this place is missing due to technical problems while coring. An estimation of the sediment accumulation rate (without taking into account the sediment compaction) from core KMDJ-12 at 3.3 and 5.4 m provide a value of $36 \mathrm{~cm} / 1000$ years. This value is consistent with the sedimentation rate value estab- 


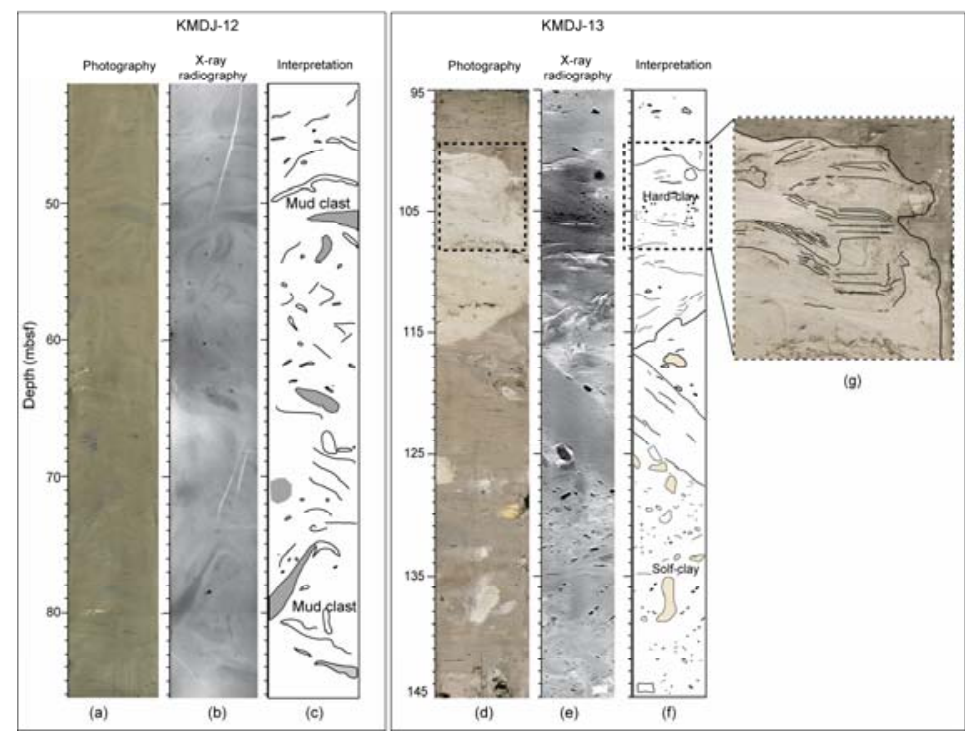

Figure 7: Interpreted images from cores KMDJ-12: a) photography, b) X-ray radiography, c) interpretation. Images from core KMDJ-13: d) photography, e) X-ray radiography, f) interpretation and g) zoom-in the indurated block.

ing the uppermost level of core KMDJ-12. lished by Giresse et al. (2008) from sediment cores recovered across the Algerian margin. The two shallowest dates in core KMDJ-14 were performed in the uppermost hemipelagic interval in order to have an estimated age of the first coarsegrained sand turbidite. The conclusions drawn from the age results are similar to those concern-

\section{Discussions and Conclusion}

The interest for studying in detail the seafloor instabilities across the Algerian margin, and in particular in the offshore area affected by the 2003 Boumerdès earthquake, stemmed from four main considerations: 1 ) the Algiers sector is tectonically active with high to moderate seismicity (maximum earthquake magnitudes around 7, Rothé et al. 1950; Yelles et al. 2009); 2) the margin has moderate slopes and irregular morphology; 3 ) there is a long historical record of earthquakes and tsunamis to which slide scars and MTDs could be linked; and 4) it is a densely populated coastal area. It has been acknowledged that the 2003 earthquake triggered landslides that probably developed downslope in submarine avalanches and caused the cables damages over around $300 \mathrm{~km}$ large area. Consequently, we searched for significant slide scars that may be linked to the release of significant volumes of sediment.

One of the main results of the present study is the multitude and small-scale slides observed across the central Algerian margin. The observed slides are small compared to those in other studied areas around the world (Booth et al. 1993; Hampton et al. 1996; McAdoo et al. 2000; Hühnerbach and Masson 2004; Sultan et al. 2004). In addition, a recent work in the western part of the Algerian margin, between the towns of Oran and Tenes, also documented small-scale slides, similar with those found in the Algiers area (Domzig et al. 2008). Therefore, no significant size slide scars or significant recent deposits were identified in the study area that could probably be related to the 2003 event.

The only large-scale slide is the B1 Slide located on the lower part of the continental slope (Fig. 3). This feature showed the presence of a deposit within the scar and out- 
runner blocks that may reach $7 \mathrm{~km}$ from the headwall. Thus, the B1 Slide is considered as a low-mobility slide. The presence of significant-size blocks far from the foot of the slope may indicate that larger blocks have longer run-out distances probably due to their larger momentum and resistance to disintegration in their downslope movement.

Smaller blocks identified near the foot of the slope are probably resulting from the disintegration of larger blocks. In addition, it has been noted that the regular spacing of the gliding tracks (about $50 \mathrm{~m}$ ) is in agreement with the size of the out-runner blocks. Results from cores showed MTDs at two different locations: upslope the headwall (KMDJ-12) and within the slide scar (KMDJ-13). The absence of a recent drape of soft clay deposits over the MTD in core KMDJ-13 could indicate a recent deposit. In spite of its upslope location, in a supposed undisturbed area, core KMDJ-12 is placed in a valley-like feature that could be interpreted as an evacuation zone (Fig. 3). Highbackscatter patches observed at the foot of the slope probably indicating the turbidity currents high activity. In addition, coarse-grained turbidite beds observed on the core KMDJ-14 testify numerous turbiditic events. The radiocarbon dates of sediment recovered at the foot of the slope (KMDJ-14) do not provide a clear answer about the age of the shallowest reworked deposits.

It has been stated that slides occur in areas with a wide range of slope gradient, ranging from 1 to $14^{\circ}$. Based on the present study and conclusions from Dan et al. (2008), the slope angle (overstepping) may be considered as a minor triggering mechanism in the central Algerian margin. Recurrent seismic activity and consequently earthquakes appears to be the main triggering factor that explains the presence of numerous small-size slides in this region. It is however difficult, with the available information, to assign the occurrence of any specific slides or deposits to the 2003 Boumerdès event. Rigorous dating of recent and past MTDs or and turbidite deposits is needed in order to achieve new insights about frequency of events and their possible connection with the Algerian seismicity.

\section{References}

Alasset PJ, Hébert H, Maouche S, Calbini V, Meghraoui M (2006) The tsunami induced by the 2003 Zemmouri earthquake ( $\mathrm{Mw}=6.9$, Algeria): modeling and results. Geophys. J. Int. doi: 10.1111/j.1365-246X.2006.02912.x

Booth JS, O'Leary DW, Popenoe P, Danforth WW (1993) U.S. Atlantic continental slope landslides: their distribution, general attributes, and implication. In: Schwab, WC, Lee HJ, Twichell DC (Eds.) Submarine landslides: Selected Studies in the U.S. Exclusive Economic Zone, U.S. Geol. Surv. Bull. 2002: 14-22.

Cattaneo A, Babonneau N, Dan G, Déverchère J, Domzig A, Gaullier V, Lepillier B, Mercier de Lépinay B, Nouguès A, Strzerzynski P, Sultan N, Yelles K (2009) Submarine slides along the Algerian margin: a review of their occurrence and potential link with tectonic structures. This volume

Dan G (2007) Processus Gravitaires et Evaluation de la Stabilité des Pentes : Approches Géologique et Géotechnique. Application à la marge algérienne et à l'effondrement de l'aéroport de Nice en 1979. PhD thesis Université de Bretagne Occidentale (UBO) spécialité Géosciences Marines. 463 pp.

Dan G, Sultan N, Savoye B, Deverchère J, Yelles K (2008) Quantifying the role of sandy-silty sediments in generating slope failures during earthquakes : example from Algerian margin. International Journal of Earth Sciences. doi 10.1007/s00531-008-0373-5.

Déverchère J (2003) MARADJA cruise report, IUEM.

Déverchère J, Yelles K, Domzig A, Mercier de Lépinay B, Bouillin JP, Gaullier V, Bracène R, Calais E, Savoye B, Kherroubi A, Le Roy P, Pauc H, Dan G (2005) Active thrust faulting offshore Boumerdès, Algeria, and its relations to the 2003 Mw 6.9 earthquake. Geophysical Research Letters 32(L04311). doi:10.1029/2004GL021646. 
Domzig A, Yelles K, Le Roy C, Dévercère J, Bouillin JP, Bracène R, Mercier de Lépinay B, Le Roy P, Calais E, Kherroubi A, Gaullier V, Savoye B, Pauc H (2006) Searching for the Africa-Eurasia Moiocene boundary offshore western Algeria (MARADJA'03 cruise). C R Geosci 338:80-91. doi:10.1016/j.crte.2005.11.009.

Domzig A, Gaullier V, Giresse P, Pauc H, Déverchère J, Yelles K (2008) Deposition processes from echo-character mapping along the western Algerian margin (Oran-Tenes), Western Mediterranean. Marine and Petroleum Geology. doi:10.1016/j.marpetgeo.2008.05.006.

France Telecom (2003) The greatest submarine cable disaster never observed. The story of the huge repairs process off Algeria. France Telecom Internal Report.

Gaullier V, Savoye B, Domzig A, Déverchère J, and the MARADJA Team (2004) Depositional patterns off Algeria from echo-character mapping (MARADJA 2003 cruise): Possible links with the recent and historical earthquakes, EGU Nice 2004, poster, EGU04-A-06232.

Giresse P, Pauc H, Déverchère J the MARADJA shipboard scientific party (2008) Sedimentary processes and origin of sediment gravity-flow deposits on the western Algerian margin during late Pleistocene and Holocene. Marine and Petroleum Geology. doi:10.1016/j.marpetgeo.2008.03.011.

Hampton MA., Lee HJ, Locat J (1996) Submarine landslides. Reviews of Geophysics 34: 33-59.

Hühnerbach V, Masson DG (2004) Landslides in the North Atlantic and its adjacent seas: an analysis of their morphology, setting and behaviour. Marine Geology. 213: 343-362.

Meghraoui M, Maouche S, Chemaa B, Cakyr Z, Aoudia A, Harbi A, Alasset PJ, Ayadi A, Bouhadad Y, Benhamouda F (2004) Coastal uplift and thrust faulting associated with the $\mathrm{Mw}=6.8 \mathrm{Zemmouri}$ (Algeria) earthquake of 21 May, 2003. Geophysical Research Letters. 31(L19605, doi:10.1029/2004GL020466).

McAdoo BG, Pratson LF, Orange DL (2000) Submarine landslide geomorphology, US continental slope. Marine Geology. 169: 103-136.

Nouguès A, Sultan N, Cattaneo A, Dan G, Yelles K, PRISME team (2009) Detailed analysis of a submarine landslide (SAR-27) in the deep basin offshore Algiers (Western Mediterranean). This volume.

Pelaez Montilla JA, Hamdache M, Casado C (2003) Seismic hazard in Northern Algeria using spatially smoothed seismicity. Results for peak ground acceleration. Tectonophysics. 372: 105- 119.

Rothé J-P (1950) Les séismes de Kherrata et la sismicité de l’Algérie. Bull. Serv. Carte Geol. Algerie Geophys. 3: 3-40.

Savoye B (2005) MARADJA2 cruise report, IFREMER.

Semmane F, Campillo M, Cotton F (2005) Fault location and source process of the Boumerdès, Algeria, earthquake inferred from geodetic and strong motion data. Geophysical Research Letter 32(L01305). doi:10.1029/2004GL021268.

Sultan N, Cochonat P, Canals M, Cattaneo A, Dennielou B, Haflidason H, Laberg JS, Long D, Mienert J, Trincardi F, Urgeles R, Vorren TO, Wilson C (2004) Triggering mechanisms of slope instability processes and sediment failures on continental margins: A geotechnical approach. Marine Geology 213, 291-321.

Yelles AK, Domzig A, Déverchère J, Bracène R, Mercier de Lépinay B, Strzerzynski P, Bertrand G, Boudiaf A, Winter T, Kherroubi A, Le Roy P, Djellit H (2009) Plio-Quaternary reactivation of the Neogene margin off NW Algiers, Algeria: The Khayr al Din bank. Tectonophysics doi:10.1016/j.tecto.2008.11.030. Corrected Proofs. TECTO-124432, 19 pp.

6 Acknowledgments Thanks go to FUGRO-France for providing the time and financial supports. Materials and financial supports were also supplied by IFREMER, the EURODOM European Project (contract RTN2-2001-00281) and the "Agence Nationale de Recherche" (projects ISIS and DANACOR) during the first author PhD. The authors appreciate the comments made by A. Bradshaw and E. Tripsanas that certainly improved the manuscript. Our thoughts go once again to Bruno Savoye who has been one of the most enthusiastic promoters of geologic exploration offshore Algeria and who is not among us anymore. 